\title{
SOME RESULTS OF AN ANALYSIS OF POLYHYDRIC ALCOHOLS EFFECT ON DETOXICATION PROCESSES
}

\author{
Viktor Konovchuk, Andrii Andrushchak \\ Department of Anesthesiology and Resuscitation, \\ Bukovinian State Medical University, Chernivtsi
}

Konovchuk V., Andrushchak A. (2015), Some results of an analysis of polyhydric alcohols effect on detoxication processes. Health Problems of Civilization, 2 (9), p. 35-38.

\begin{abstract}
Summary: Rheosorbilact action on antitoxic function of the kidneys has been analysed using the values of medium weight molecules in patients with severe sepsis. The study design includes the criteria of inclusion, exclusion and cessation. Patients with pyoceptic complications (mainly surgical abdominal sepsis) with signs of severe endotoxicosis, dopaminergic activity (5-10 mcg/kg min), biochemical criteria of SS (lactate $>4$ mmole/l, C-reactive protein $>2$ standard departures from the norm) and other signs of severe sepsis with generalized disorders in homeostasis (assessing the multiple organ damage course by H.Celye-I.A. Yeriuhin scale- 20-27 points, MODS scale - 6-10 points) corresponded to the inclusion criterion. All patients were provided with appropriate debridement and intensive traditional therapy.

For control studies we involved patients with systemic inflammatory response syndrome who had 2-3 signs of SIRS in stage A. It was found that rheosorbilact activates the transportation of medium weight molecules out of the extracellular space and increases their excretion by the renal nephrons in patients with severe sepsis. It was established that in severe sepsis rheosorbilact provides a high level of excretion of medium weight molecules by suppressing processes of reabsorption in the proximal nephron portions caused by peptidase dependent metabolism.
\end{abstract}

Keywords: severe sepsis, rheosorbilact, endotoxicosis, medium weight molecules

\section{Introduction}

Severe sepsis, complicated by multiple organ damage, is a topical issue nowadays (Dellinger et al. 2008, Levy et al. 2003). At all stages of development and formation of multiple organ damage endotoxicosis manifest itself (Chong, Dumont 2015). The composition of toxic substances that form endotoxicosis include medium weight molecules (MWM) with quite high biological activity. In particular, they are characterized by neurotoxic, cardiotoxic, hepatotoxic and nephrotoxic activity. Its organotropic action is based on the property to inhibit protein biosynthesis, several enzymes; to separate oxidation and phosphorylation; to carry toxic effects on erythropoiesis, to cause secondary immunosuppression, etc. (Peirrakos, Vincent 2010).

In intensive care for endotoxicosis intra- and extracorporeal methods are used (Marshall, Reinhart 2009). The most common and affordable method of intracorporeal detoxification is the use of different infusion solutions (Mouncey, Osborn 2015). However, the effect of derivatives of polyhydric alcohols such as rheosorbilact on detoxification processes mediated by renal function in patients with severe sepsis (SS) has not been studied (Quintero, Martinez 2015).

\section{The objective of study}

To analyse the action of rheosorbilact on toxicokinetics of medium weight molecules in patients with severe sepsis.

Address for correspondence: Viktor Konovchuk, Department of Anesthesiology and Resuscitation, Bukovinian State Medical University, Teatral'na square, 2, Chernivtsi, Ukraine, 58000, phone: +380 372553 754, e-mail: office@bsmu.edu.ua

Tables: 1 Figures: 0 References: 10 Full-text PDF www.hpc.edu.pl Copyright $($ Pope John Paul II State School of Higher Education in Biała Podlaska, Sidorska 95/97, 21-500 Biała Podlaska Indexation: Index Copernicus, AGR0, ProQuest, Polish Medical Bibliography, Polish Ministry of Science and Higher Education. This is an open-access article distributed under the terms of the Creative Common Attribution Non-commerciallicense (http://creativecommons.org/licenses/by-nc/3.0), which permits use, distribution and reproduction in any medium, provided the original works is properly cited, the use is non-commercial and is otherwise in compliance with the license. 


\section{Materials and methods}

The study belongs to open, randomized, prospective and controlled ones. The study design includes the criteria of inclusion, exclusion and cessation. Patients with pyoceptic complications (mainly surgical abdominal sepsis) with signs of severe endotoxicosis, dopaminergic activity (5-10 mcg/ $\mathrm{kg} \mathrm{min}$ ), biochemical criteria of SS (lactate $>4$ mmole/l, C-reactive protein $>2$ standard departures from the norm) and other signs of severe sepsis with generalized disorders in homeostasis (assessing the multiple organ damage course by H.Celye-I.A. Yeriuhin scale- 20-27 points, MODS scale - 6-10 points) corresponded to the inclusion criterion. All patients were provided with appropriate debridement and intensive traditional therapy (Chang, Peng 2013).

For control studies we involved patients with systemic inflammatory response syndrome who had 2-3 signs of SIRS in stage A (Dellinger et al. 2013). The patients were divided into four groups. Groups I and II included patients with systemic inflammatory response syndrome $(n=45)$ and they were subjected to control studies, groups III-IV had severe sepsis $(\mathrm{n}=55)$. They all received infusion load in the form of isotonic $\mathrm{NaCl}$ solution in an amount of $7.8 \mathrm{ml} / \mathrm{kg}$ at a speed of $18-20 \mathrm{ml} / \mathrm{min}$ (group I, group III) or rheosorbilact in the same infusion mode (group II and group IV). Toxicity of biological fluids were determined by the level of MWM using A.Babel method. The results of the research have been processed using the method of variation statistics by Fischer (Student test) using the IBM PS (EXCEL software).

\section{Results and discussion}

The influence of rheosorbilact on detoxication renal function in patients with severe sepsis has been studied (Eremenko, Medvedeva 2013).

It should be noted that rheosorbilact ( 900 mosm / l) due to its high osmolarity initiates fluid intake from intercellular spaces into the bloodstream which improves microcirculation, tissue perfusion and increases blood volume. It also has osmodiuretic action (a human beeing has no natural mechanisms of reabsorption of polyhydric alcohols). Sorbitol is partly metabolized to fructose, which helps normalize carbohydrate metabolism. Sorbitol stimulates the oxidation of fatty acids by non-ketogenic metabolism way and contributes to a simpler use of ketone bodies in the Krebs cycle. It restores glycogen depot in the liver, improves functional status of hepatocytes, increases intestinal motility. It neutralize metabolic acidosis, reduces the need for adrenoceptors, improves rheology, reduces the severity of the intestinal flora translocation syndrome, optimizes splanchnic circulation, prevents the development of stress ulcers of the stomach and intestines, stimulates neutrophil phagocytosis, prevents the development of hepatorenal failure.

By means of endotoxicosis objectification calculations of kinetic parameters of MWM were selected.

The components of endotoxicosis in severe sepsis are MWM (MW - 300-5 000 D). They are freely filtered by the glomeruli and create a high concentration in the ultrafiltrate of proximal nephron portion. There the main amount of MWM by means of a system of nephrothelial peptidases is metabolized into amino acids that are reabsorbed. Some MWM are excreted by the kidneys. Therefore, the elimination of MWM activity depends on the speed of glomerular filtration and proximal metabolism. Given that MWM are a part of substances which cause endotoxicosis, consideration of renal participation in the elimination of toxemia components in severe sepsis is an interesting question for determining the tactics of infusion therapy for endotoxicosis. The findings of these studies are listed in the table.

Table 1. Rheosorbilact influence on detoxication renal function in patients with severe sepsis based on the values of the medium weight molecules

\begin{tabular}{|c|c|c|c|c|c|}
\hline Values & Condition & $\begin{array}{c}\text { SIRS, EESV 0,9\% sol. } \\
\mathrm{NaCl} \\
\text { I gr. } \mathrm{n}=21\end{array}$ & $\begin{array}{l}\text { SIRS, EESV with } \\
\text { rheosorbilact II gr. } \\
n=24\end{array}$ & $\begin{array}{l}\text { SS, EESV 0,9\% sol. } \\
\text { NaCl III gr. } n=27\end{array}$ & $\begin{array}{c}\text { SS, EESV with } \\
\text { rheosorbilact IV gr. } \\
n=28\end{array}$ \\
\hline $\begin{array}{l}\text { MWM concen- } \\
\text { tration in blood } \\
\text { plasma, s.u../ml }\end{array}$ & $\begin{array}{l}\text { A } \\
\text { B }\end{array}$ & $\begin{array}{l}0,26 \pm 0,012 \\
0,25 \pm 0,013\end{array}$ & $\begin{array}{l}0,27 \pm 0,011 \\
0,24 \pm 0,012\end{array}$ & $\begin{array}{l}0,66 \pm 0,026^{* *} \\
0,61 \pm 0,025^{* *}\end{array}$ & $\begin{array}{c}0,64 \pm 0,021^{* *} \\
0,68 \pm 0,020^{*} * *\end{array}$ \\
\hline $\begin{array}{c}\text { MWM } \\
\text { concentration in } \\
\text { urine s.u../ml } \\
\end{array}$ & $\begin{array}{l}\text { A } \\
\text { B }\end{array}$ & $\begin{array}{l}4,9 \pm 0,26 \\
2,7 \pm 0,15 \\
\quad * * *\end{array}$ & $\begin{array}{l}5,1 \pm 0,23 \\
3,1 \pm 0,17 \\
\quad * * *\end{array}$ & $\begin{array}{l}14,7 \pm 0,59^{* *} \\
14,1 \pm 0,61^{* *}\end{array}$ & $\begin{array}{l}14,5 \pm 0,51^{* *} \\
15,2 \pm 0,60^{* *}\end{array}$ \\
\hline $\begin{array}{l}\text { MWM excretion } \\
\text { s.u../min }\end{array}$ & $\begin{array}{l}\text { A } \\
\text { B } \\
\text { p }\end{array}$ & $\begin{array}{c}4,75 \pm 0,29 \\
6,14 \pm 0,41 \\
* * *\end{array}$ & $\begin{array}{c}4,69 \pm 0,25 \\
8,74 \pm 0,49 * \\
* * *\end{array}$ & $\begin{array}{c}12,50 \pm 0,78^{* *} \\
24,25 \pm 1,43^{* *} \\
* * *\end{array}$ & $\begin{array}{c}12,18 \pm 0,69^{* *} \\
41,19 \pm 2,17^{* * *} \\
* * *\end{array}$ \\
\hline
\end{tabular}




\begin{tabular}{|c|c|c|c|c|c|}
\hline $\begin{array}{l}\text { MWM clearance } \\
\mathrm{ml} / \mathrm{min}\end{array}$ & $\begin{array}{l}\text { A } \\
\text { B }\end{array}$ & $\begin{array}{c}18,27 \pm 1,08 \\
24,56 \pm 1,64 \\
* * *\end{array}$ & $\begin{array}{c}17,37 \pm 0,97 \\
36,42 \pm 1,82^{*} \\
* * *\end{array}$ & $\begin{array}{c}18,94 \pm 1,12 \\
39,75 \pm 2,38^{* *} \\
* * *\end{array}$ & $\begin{array}{c}19,03 \pm 1,03 \\
60,57 \pm 3,78^{* * *} \\
* * *\end{array}$ \\
\hline $\begin{array}{c}\text { MWM excretion } \\
\text { intensity } \\
\text { For } 100 \mathrm{ml} \text { of } \\
\text { glomerular filtrate, } \\
\text { s.u./min }\end{array}$ & $\begin{array}{l}\text { A } \\
\text { B }\end{array}$ & $\begin{array}{c}4,09 \pm 0,24 \\
5,12 \pm 0,32 \\
* * *\end{array}$ & $\begin{array}{c}4,11 \pm 0,23 \\
6,76 \pm 0,37 * \\
* * *\end{array}$ & $\begin{array}{c}18,11 \pm 1,01^{* *} \\
34,15 \pm 1,64^{* *} \\
* * *\end{array}$ & $\begin{array}{c}18,18 \pm 1,07^{* *} \\
39,97 \pm 1,91^{*} * * \\
* * *\end{array}$ \\
\hline $\begin{array}{l}\text { I group.-Syst } \\
0,9 \% \text { solutio } \\
\text { II gr. - SIRS, } \\
\text { III gr. - sever } \\
\text { IV gr. - SS, EE } \\
\text { A - patients b } \\
\mathrm{B}-\text { patients a } \\
* / \mathrm{p} \leq 0,05-\mathrm{re} \\
* * / \mathrm{p} \leq 0,05-\mathrm{r} \\
* * * / \mathrm{p} \leq 0,05-\end{array}$ & $\begin{array}{l}\text { Na } \\
\text { Vwi } \\
\text { psi } \\
\text { wit } \\
\text { re } \\
\text { r EE } \\
\text { ilit } \\
\text { bili }\end{array}$ & $\begin{array}{l}\text { ory Response } \\
\text { orbilact; } \\
\text { SV with 0,9\% } \\
\text { rbilact; } \\
\text { setween I a } \\
\text { es between I } \\
\text { ues between }\end{array}$ & $\begin{array}{l}\text { me (SIRS); Enl } \\
\text { of NaCl; } \\
\text { ups, III and IV } \\
\text { roups, II and I } \\
\text { ns A and B. }\end{array}$ & of extracellu & 更 \\
\hline
\end{tabular}

In severe sepsis (III- IV gr.) MWM concentration in plasma is high $(\mathrm{p}<0.05)$. After the enlargement of extracellular space volume EESV with infusion solutions (condition B), this figure does not undergo significant changes. But it (condition A) defined the value of filtration fraction of MWM $(30.8+0.71$ s.u. / min. - group 2., $43.9+0.91$ s.u. / min. - IV gr. $\mathrm{p}<0.05$ ) because the value of glomerular filtration rate in these groups was 114 $+2.3 \mathrm{ml} / \mathrm{min}$. and $67+2.3 \mathrm{ml} / \mathrm{min}$. respectively $(\mathrm{P}<0.05)$. Further formation of excretion rate of MWM is controlled by the processes of reabsorption. Thus, the relative reabsorption of MWM in the second group was $84.8+3.07 \%$, and in the fourth gr. $-71.6+2.77 \%(\mathrm{p}<0.05)$, which contributed to higher levels of MWM excretion in patients with severe sepsis (condition A). EESV (rheosorbilact) in these groups of study by an increase in glomerular filtration rate (Д, $13+4.8 \%$ - group II., Д, $36+7.8 \%$ - IV gr., $P<0.05$ ) and a decrease in fractional reabsorption (Д, $14+6.2 \%$ - group II., Д, $30+6.7 \%$ - IV gr., $\mathrm{p}<0.05$ ) resulted in nearly a fivefold increase in the excretion of MWM in patients with severe sepsis. In this context, high efficiency of Sorbilactum is observed as compared to the third group as well.

Comparison of clearance characteristics of MWM (condition A-IVgr.) with corresponding indices of standardized intensity of excretion suggests that in order to provide plasma cleaning of MWM the active nephrons of severe sepsis patients have the function which is more significant ( $>4$ times) than in patients with Systemic Inflammatory Response Syndrome (normal response to stress, characterized by a moderate decrease in systemic vascular resistance and a corresponding increase in cardiac output, physiological arteriovenous oxygen content difference, increased cardiac index, increased oxygen consumption and normal lactate concentration. Given that the glomerular filtration rate in patients with severe sepsis is less than the target figures and inhibition of reabsorption of MWM is more significant, you should pay attention to the mechanisms of transportation of MWM, namely their metabolism in the nephrocytes of the proximal nephron part which is mediated by a system of peptidases. It means that in severe sepsis there is inhibition of peptidases, and thus metabolism of MWM, which leads to their increased excretion and clearance characteristics formation. This is especially true with rheosorbilact (condition B, IV gr.).

\section{Conclusions}

1. Rheosorbilact activates MWM transportation from the extracellular space and increases their excretion by nephrons of the kidneys in patients with severe sepsis.

2. Analysis of the research of rheosorbilact action on clearance characteristics of MWM indicates its high curative abilities.

3. The guiding factor in ensuring a high level of MWM excretion in severe sepsis, especially under rheosorbilact action is inhibition of their reabsorption in the proximal nephron portions due to the peptidase dependent metabolism. 


\section{References:}

1. Chang P., Peng S. (2013), Fluid resuscitation strategy in septic shock following urinary infection with severe pulmonary capillary leakage. Zhonghua Wei Zhong Bing Ji Jiu Yi Xue. 2013 Jan;25(1):14-8.

2. Chong J., Dumont T. (2015), Sepsis and septic shock: a review. Crit Care Nurs Q. 38(2):111-20.

3. Dellinger R.P., Levy M.M., Carlet J.M. (2008), Surviving Sepsis Compaign: International guidelines for management of sever sepsis end sepsis shok: 2008, Intesive Care Med. Vol.34(1), 17-60.

4. Dellinger R.P., Levy M.M., Rhodes A. (2013), Surviving Sepsis Campaign: internationalguidelines for management of severe sepsis and septic shock: 2012, Crit Care Med. Vol. 41, 580-637.

5. Eremenko A.A, Medvedeva L.A. (2013), The efficacy of the rheosorbilact during the cardiovascular surgery. Khirurgiia (Mosk). 2013;(8):59-66.

6. Levy M.M., Fink M.P., Marshall J.C. (2003), 2001 SCCM/ESICM/ACCP/ATS/SIS International sepsis Definitions Conference, Crit Care Med. Vol.31, 1250-1256.

7. Marshall J.C. Reinhart K. (2009), Biomarkers of sepsis, Crit. Care Med. Vol.37, 2290-2298.

8. Mouncey P.R., Osborn T.M. (2015), Trial of early, goal-directed resuscitation for septic shock. N Engl J Med 372 (14): 1301-11.

9. Peirrakos C., Vincent J.L. (2010), Sepsis biomarkers: a review, Crit. Care. Vol.14, R15.

10. Quintero R.A., Martínez C.A. (2015), Adherence to international guidelines on early management in severe sepsis and septic shock. Biomedica. 2012 Sep;32(3):449-56. 